\title{
Toward a National Hungarian Army: The Military Compromise of 1868 and Its Consequences
}

In discussing the Ausgleich of 1867 historians generally focus on the complex political and economic arrangements and pay little attention to the military controversy over the problem of restructuring the Habsburg army. Yet this problem almost prevented conclusion of the political agreement and greatly endangered its implementation. Count Julius Andrássy, one of the leading Hungarian negotiators, called it the "sword of Damocles suspended over our heads," and the common war minister, Franz Baron Kuhn, believed that "the future existence of the monarchy" depended on "a successful solution of the army question."2

The issue was, of course, ancient. Ever since 1526, when Ferdinand I assumed the crown of Hungary, there had been aspirations for a separate and independent Hungarian military establishment. But until the kingdom had been liberated from the Turks the Hungarians had little opportunity to press their demands. The problem became acute when after the Treaty of Karlowitz the Habsburg began to raise standing forces in the country. In the end, and as part of the arrangements leading to acceptance of the Pragmatic Sanction by the Diet of 1722-23, a compromise was struck. The sovereign was invested with the actual command and control of the army, and an executive body of the Diet, the Consilium Locumtenale Hungaricum, became responsible for recruitment and supply..$^{3}$ This arrangement, which vested considerable power in the Diet, continued for most of the century. In 1790, however, following Joseph II's discomfiture during the Turkish War, the Diet called for the creation of a national army commanded by Magyar officers. ${ }^{4}$ The French Revolution intensified national feelings, and in 1802 the Diet renewed its demands for an exercitus hungaricus. ${ }^{5}$ During the Diet of $1839-40$ there were demands that all

1. Andrássy to Francis Joseph, July 17, 1868, Kriegsarchiv (henceforth KA), Militärkanzlei seiner Majestät (MKSM), Sonderreihe F 29 (a) 3.

2. Cited in Walter Wagner, Geschichte des k.k. Kriegsministeriums II, 1866-1888 (Vienna, 1971), p. 48. 104-5.

3. Béla K. Király, Hungary in the Late Eighteenth Century (New York, 1969), pp.

4. Anton Radvánszky, "Das ungarische Ausgleichsgesetz vom Jahre 1867," in Forschungsinstitut für den Donauraum, Der österreichisch-ungarische Ausgleich vom Jahre 1867 (Vienna and Munich, 1967), pp. 91-92.

5. Johann Christoph Allmayer-Beck, "Der Ausgleich von 1867 und die k.u.k. bewaffnete Macht," ibid., pp. 116-17. 
indigenous troops should wear the Hungarian insignia, use the Hungarian language of command, and be commanded only by Hungarian officers. ${ }^{8}$ Finally, in 1848, Hungary's assertion of complete military independence was one of the major reasons for the break with Vienna. ${ }^{7}$

Although the imperial army, albeit with Russian help, weathered the revolution and eventually reconquered Hungary with bayonet and grapeshot, the dynasty did not forget Hungary's defection. It regarded the imperial army as the main guarantor of its rule and looked on all nationalist aspirations with utmost suspicion. "In no other country," declared Archduke Albrecht, the leading military figure of the dynasty, "is unity, uniformity, and the dynastic soldierly spirit as all-important . . . because only the dynasty and the army can hold this monarchy together." 8 But by regarding the army primarily as a guarantor of the dynasty, the Habsburgs failed to recognize that the new forces unleashed by the industrial revolution required mass armies supported by the socioeconomic potential of the entire population. ${ }^{9}$ Locked into its dynastic posture the Habsburg army deteriorated as a fighting force. After the Italian debacle in 1859 the dynasty found it necessary to conciliate Hungary, and the defeat in 1866 forced a reluctant emperor to come to an overall accommodation with the Magyars, which included a reopening of the military question.

Negotiations with the Magyars had already begun before the war with Prussia and the Hungarian Diet had been reconvened in December 1865. To conduct negotiations the Diet named a Committee of Sixty-seven, which in turn formed a Select Committee of Fifteen with Andrássy and Ferencz Deák as its guiding spirits. When, after being interrupted by the war, negotiations resumed in late July 1866 , a committee minority, led by Kálmán Tisza, claimed that the Pragmatic Sanction only required a common defense and not a unitary army. The time had come, the group claimed, to demand a national Hungarian force. Aware, however, that Vienna even now would never accept a complete division of the army, Andrássy and Deák, supported by the majority, argued for a continuation of the unitary army in return for substantial military concessions. And when this division of opinion could not be resolved, the committee decided to shelve the army issue temporarily in order not to block the progress of the political negotiations. ${ }^{10}$

6. George Barany, "The Hungarian Diet of 1839-40 and the Fate of Széchenyi's Middle Course," Slavic Review, 22 (1963): 297-98.

7. Gunther E. Rothenberg, "Ban Jelačic, the Croatian Military Border, and the Intervention Against Hungary," Austrian History Yearbook, 1 (1965): 55-56. 126.

8. Cited in Heinrich v. Srbik, Aus Osterreichs Vergangenheit (Salzburg, 1959), p.

9. Antonio Schmidt, "Die Armee in Osterreich von 1848-1867" (Ph.D. diss., University of Munich, 1960), 2 vols., typescript, 2:32.

10. Ivan Žolger, Der staatsrechtliche Ausgleich zwischen Österreich und Ungarn (Leipzig, 1911), pp. 5-13. 
Despite his more moderate stand, Andrássy, now prime minister designate of the new Hungarian government, was determined to assert his country's position in military affairs. When in the aftermath of Königgrätz the emperor instituted hasty measures to raise the army's fighting strength and in December 1866 introduced conscription throughout the empire, Andrássy protested.11 The decree, he declared, was a "flagrant violation of the nation's rights," and any basic changes in the military structure could be accomplished only by constitutional processes and not by imperial fiat. In the face of this stand the emperor retreated and the order was retracted. ${ }^{12}$

Nonetheless, Andrássy realized that a solution to the army issue had to be found unless the Ausgleich, then in its final stage of negotiation, was to founder. Under his prodding the Committee of Fifteen agreed in January 1867 to accept the old interpretation of the Pragmatic Sanction. The sovereign, it ruled, held exclusive command over the army, but the Hungarian parliament was to be responsible for recruitment, supply, and quartering within the kingdom. ${ }^{13}$ Although this fell far short of aspirations for a national army, the ruling opened the way to the final political settlement. In February 1867 parliamentary government was restored in Hungary and Andrássy assumed office as prime minister.

The final version of the Ausgleich document reflected the position adopted by the committee, though the language was deliberately obscure. Article 11 stipulated that "in accordance with the constitutional prerogatives of the sovereign all matters relating to the command and the internal administration of the entire army, and therefore also of the Hungarian army as an integral part of the entire military establishment, are recognized as being reserved to His Majesty." Terms of service, quartering, and financial support were declared to be subject to approval (article 12), and all basic changes in the military system affecting Hungary required the consent of the Hungarian ministry (article 13). ${ }^{14}$

Of course, the reference to the "Hungarian army as an integral part of the entire military establishment" indicated that some concessions would have to be made to Hungary, and the very thought of a national Hungarian army was anathema to the military leaders led by Archduke Albrecht. On February 20,1867 , Albrecht, in his capacity as commanding general of the armies, issued an order denouncing military separatism. He acknowledged the estab-

11. For the imperial order, Dec. 28, 1866, KA MKSM 1867 82-1/1-2. For Andrássy's reaction see Eduard v. Wertheimer, Graf Julius Andrassy, 3 vols. (Stuttgart, 1910-13), $1: 250$.

12. KA MKSM $186782-5 / 1$.

13. Żolger, Der staatsrechtliche Ausgleich, pp. 34-39; Julius Miskolczy, Ungarn in der Habsburger Monarchie (Vienna and Munich, 1959), pp. 135-36.

14. Žolger, Der staatsrechtliche Ausgleich, pp. 20-37. 
lishment of a separate Hungarian ministry of national defense, but proclaimed, "The army has not changed in the close unity of its components." $15 \mathrm{He}$ fought the appearance of a separate Hungarian army, at court and in ministerial councils, and even took his case to the public in a number of pamphlets in which he assailed "political machinations and the glorification of traitors," and asserted that the peoples of the monarchy cherished the traditional unifying Armeegeist and rejected the divisive Magyar Regimentsgeist. ${ }^{\mathbf{1}}$ In Hungary, meanwhile, the opposition parties exploited Albrecht's activities for their own purposes. They introduced motion after motion attacking the government for its failure to achieve a national army, delayed the introduction of legislation implementing a new recruitment system, and put the whole structure of the Ausgleich in danger. ${ }^{17}$

With conscription suspended and the reorganization of the army stalled, Vienna grew more and more impatient during the fall of 1867. If Austria was to recover her position as a great power, army reform was mandatory, and the Hungarian delay raised the specter of a serious confrontation between the two halves of the monarchy. To break the impasse Emperor Francis Joseph in November 1867 ordered a council of generals to meet in order to work out a comprehensive army reform plan. It was a sign of the changed times that he instructed the council on the one hand to observe the new constitutional framework, but on the other it was to guard zealously the unity of the army and preserve the old traditions. ${ }^{18}$ Moreover, he sent the trusted head of his military chancery, Colonel Friedrich Beck, to negotiate directly with Andrássy.

At the outset of his mission Beck was a determined supporter of a unitary army. In a series of memoranda he tried to convince Andrássy that Hungary could not stand alone and that an independent Hungarian army would become a center of social unrest and provoke similar demands from the Slavic nationalities within the Dual Monarchy. ${ }^{19}$ But Andrássy, facing an angry opposition and an aroused country, could not be shaken from his demand for further concessions. However, he now proposed a joint imperial-royal (k.k.) army controlled by the emperor and the establishment of separate Austrian and

15. The order, a circular to all commanding generals, stated further that troops should be isolated from subversive influences by strict discipline and constant surveillance. See KA Kriegsministerium Präsidial (KM Präs.) 1867 44-46. Also Edmund v. GlaiseHorstenau, Franz Josephs Weggefährte: Das Leben des Generalstabschef Grafen Beck (Zurich and Vienna, 1930), pp. 144-45.

16. Anon. [Albrecht], Wie soll Oesterreichs Heer organisiert sein (Vienna, 1869), pp. 19-20.

17. Walter Rogge, Oesterreich von Vilàgos bis-zur Gegenzvart, 3 vols. (Leipzig and Vienna, 1873), 3:148-50.

18. KA MKSM $186782-5 / 1$.

19. "Gegen die Zweiteilung der Armee," Nov. 27, 1867, in KA MKSM 1868 82-3/20; MKSM Sonderreihe F 29 (a) 6, and Nachlass Beck (A 2) 143. 
Hungarian national guards (Landwehr and Honvédség) which were to be under the respective ministries of defense, who also represented the crown in putting the votes for them to the parliaments. ${ }^{20}$ Moreover, Andrássy conceded the German language of command for the joint army and promised that he would not press for the dissolution of the Military Borders. On the whole, Beck was well impressed and noted in his report that considering the temper of the country Andrássy's position was most courageous. ${ }^{21}$ In Vienna, however, Albrecht was not so easily convinced. The existence of national guards, he argued, would provide military training for subversive elements, and at the same time it would induce the two parliaments to reduce their appropriations for the joint army, the only reliable force safeguarding the established order. ${ }^{22}$

Similar fears and objections were voiced by the generals when the council, summoned by Francis Joseph, finally met at the end of February 1868. Some general declared that regardless of the imperial wishes, the unity of the army and its historical legitimacy had to be preserved, and no concessions should be made just to preserve the Andrássy government from its parliamentary opposition. A break with Hungary, asserted Feldmarschall Leutnant Karl Möring, was probably unavoidable in any case, and he compared Andrássy's assurances with those made by the Prussians at Gastein shortly before the outbreak of war in 1866. Feldmarschall Leutnant Ludwig Baron Gablenz replied that this contravened the wishes of the emperor, but Feldmarschall Leutnant Count Bigot de St. Quentin countered that the army was the last and only secure pillar of the monarchy and had to be preserved at all costs. In the end, however, the habit of obedience reasserted itself, and the generals bowed, reluctantly, to the imperial wishes. On March 23 they reported their basic acceptance of Andrássy's proposals. ${ }^{28}$

But this was not yet the end of the controversy. The Hungarians wanted to recreate in organization, uniform, and drill the revolutionary Honvéd of 1849, and this was totally unacceptable to Francis Joseph and the military leaders. In April 1868 a series of conferences attended by the ministers of defense, the common war minister, Count Friedrich Ferdinand von Beust, the emperor's chief adviser and minister for foreign affairs, Andrássy, and chaired

20. At this point Beck conceived the national guards as a militia on the Tyrolean pattern, constituted from men over thirty years of age released from the reserves, and employed primarily on internal security duties. Only in times of war was this force to act with the army, and then merely as an auxiliary. See KA Nachlass Beck (A 2) 143 and MKSM 1868-3/20. In the final disposition, of course, the Honvédség was rather different from the force envisaged by Beck.

21. KA MKSM Sonderreihe F 7636 and Nachlass Beck (A 2) 144. B $138-22$.

22. Albrecht to War Minister Baron von John, December 1867, KA Nachlass John

23. Protocols and position papers, KA KM Präs. 29-1/1-8. Kuhn's report to Francis Joseph, Mar. 27, 1868, ibid., $3 / 1$. 
by the emperor himself, took place in Buda, but failed to resolve the latest deadlock. ${ }^{24}$ In the end the diplomatic Beck once again came to the rescue, and in personal discussion with Andrássy he resolved the deadlock in May. The new Honvédség was to be patterned after the joint army in organization and uniform, but its oath of allegiance would be to the Hungarian king as well as to the national constitution. Moreover, it would be authorized distinctive insignia, flags, and the Hungarian language of command. The solution was acceptable to the emperor and pleased Andrássy, who on June 17, 1868, congratulated Francis Joseph on the "resolution of a problem which . . . in the past has bitterly divided the monarchy." 25

Congratulations, however, were rather premature, because Andrássy, still facing a clamorous opposition, promptly made additional demands. Above all he now demanded that the Honvédség, originally restricted to infantry and cavalry only, must receive its full allocation of artillery. But this demand, which would have given the Hungarian units the same combat potential as the joint army, was refused by the emperor, with the strong support of Albrecht and Kuhn. ${ }^{26}$ At this point Andrássy, always a political realist, decided that he had reached the full extent of concessions available, and in order not to endanger the political settlement which had given Hungary parity in the Dual Monarchy, he pushed the military settlement through parliament. However, and this was a portent of things to come, in order to quiet the vehement objections of the opposition, he had to promise that the government would continue to press with all available means for greater military autonomy. ${ }^{27}$

At the same time similar legislation was piloted through the parliament in Vienna, though here, too, there was opposition. More important, outside of parliament the military leadership was still recalcitrant, and in August 1868, during a tour of inspection in Croatia, Albrecht made a symbolic pilgrimage to the grave of Ban Jelačić. ${ }^{28}$ Although the meaning of this action was not lost on either Vienna or Buda, this was 1868 and not 1848. The emperor, "who always maintained and protected ... the compromise law from a strictly Magyar point of view," ${ }^{29}$ would tolerate no further obstruction. Once both parliaments had passed the necessary legislation, implementation was rapid. On December 5,1868 , Francis Joseph issued a carefully worded order of the day. "A new element, the Landwehr (Honvédség)," the order ran, "today joins the

24. KA MKSM Sonderreihe F 29 (a) 2-5e.

25. Ibid., 3.

26. Kuhn to Francis Joseph, telegram, ibid., 6. Cf. Srbik, Aus Osterreichs Vergangenheit, p. 184.

27. Wertheimer, Graf Julius Andrássy, 1:361-63.

28. Ibid., p. 355 .

29. The view of an old Habsburg loyalist of liberal views, Joseph Redlich, Emperon Francis Joseph of Austria (New York, 1929), pp. 352-53. 
army as a valuable augmentation of the common defense." The new organizations, the order continued, "serve the same purpose as the army . . . and I expect that all officers ... and in particular the generalcy will do their utmost to further the bonds between all components of My Army and they will strengthen the spirit of order and discipline and combat any potentially divisive and dangerous influences from the very start." ${ }^{30}$

This was strong language indeed, and it settled, for the moment at least, any attempts by the military leadership to oppose the new order. At the same time, however, the order glossed over the full extent of the Hungarian victory. The statement that Landwehr and Honvédség merely augmented the army evaded the fact that Buda never considered the Honvédség merely a secondline home guard, but rather regarded it as the first step to a fully equipped, completely independent national army. Under the provisions of the army legislation of 1868 , and further implementing legislation passed early the following year, all male subjects of the monarchy were liable for a total of twelve years of military service. The annual recruit intake was set at 95,000 , of which Austria provided 55,000 and Hungary 40,000 men. The intake was then apportioned by lot. Those drawing the lowest numbers were inducted for three years into the joint army, then placed for seven years in the army reserves, and finally transferred to the Landwehr or Honvédség for their last two years. The small number drawing the middle lots spent two years of active service in the national formations. Finally, those drawing the highest numbers received no training at all but were placed in the supplementary reserve, the Ersatz Reserve, subject to call only in time of war. ${ }^{31}$

Both Landwehr and Honvédség were usually cadre formations only, and their full complement-old soldiers, reservists, and recruits-was to be called out only for an annual muster, a two-week drill period, and biannual battalion exercises. Moreover, until the last decade before the outbreak of war in 1914, the war ministry in Vienna regarded the national armies as secondary, and supplied them only gradually with new weapons and equipment. ${ }^{32}$ Still, much of the financing and the procurement of equipment was in the hands of the national defense ministries, and the build-up of the two forces did not proceed at an equal pace in the two halves of the monarchy. From the outset the Honvédség received liberal support from the Hungarian parliament. Although its nominal commander since 1868 was Archduke Joseph, ${ }^{33}$ its real governance

30. The order was most carefully phrased; there exist no less than five different drafts. KA MKSM 82-3/14.

31. Heinrich v. Nauendorff, Die Kriegsmacht Oesterreichs, 2nd ed., 3 vols. (Vienna, 1875-76), 1:16-39.

32. "Ausbau der Landwehr," KA MKSM 1914 82-1/1-1. See also the annual "Schlagfertigskeitberichte," a unique feature of the Austro-Hungarian armed forces.

33. Appointment, Dec. 5, 1868, KA MKSM 82-3/17. 
was in the hands of the minister of national defense, a portfolio held until 1872 by the prime minister. In 1872 Bẻla von Szende took over that office, with Major General Géza Baron Fejérváry acting as military secretary. Annual expenditures for the Honvédség were in excess of nine million florins, though during the financial crisis of 1873 the allocation was reduced to seven million for 1874 and to six million for the next year. Late in 1877 , however, parliament restored most of the cuts and voted additional funds to equip the Honvéds with modern arms. ${ }^{34}$

As a result of these efforts the organization grew rapidly, and by 1873 it already numbered 2,868 officers and 158,000 men, organized in eighty-six battalions and fifty-eight squadrons. Many of the original officers either were veterans of 1849 or transfers from the joint army, but in 1872 the Ludovika Academy, formerly a military preparatory school, opened first as a cadet and later as a staff college for the Honvédség. In 1870 Honvéd brigades participated for the first time in army maneuvers, and in 1873 higher tactical formations and territorial commands, seven divisions and seven military districts, were organized. Of course, these units still lacked artillery, although in August 1870 an attempt to circumvent these restrictions by the formation of twenty Gatling-gun batteries was successful. Kuhn protested, but the emperor ruled that these pieces were infantry weapons, not artillery. ${ }^{35}$ By the end of the seventies, then, the Honvédség approached, at least in infantry and cavalry if not yet in artillery and auxiliary services, the stature of a national army. ${ }^{30} \mathrm{By}$ contrast the Landwehr, largely established to maintain the appearance of parity, had made little progress and still consisted only of skeleton infantry units brigaded for administrative purposes with units of the joint army. ${ }^{37}$

Hungary made another significant step in furthering her goal of total military autonomy. For several hundred years the Military Borders, special administrative districts where the entire population was subject to military law, had been centrally administered from Vienna and on occasion were used

34. Ludwig Jedlicka, "Vom Kaiserthum Osterreich zur Doppelmonarchie ÖsterreichUngarn," in Wolfgang v. Groote and Ursula v. Gersdorff, eds., Entscheidung, 1866 (Stuttgart, 1966), p. 269. Also consult the figures in the annual Militärstatistische Jahrbücher, which show an almost double intake of recruits for the Honvédség compared with the Landwehr.

35. KA MKSM $18701 / 45$. The Gatling batteries were dissolved only in 1875 when they had proved not practical. Cf. Alphons v. Wrede, Geschichte der k.u.k. Wehrmacht, 5 vols. (Vienna, 1898-1905), 5:557. See also Haus-, Hof- und Staatsarchiv, Politisches Archiv, Militaria, Box 560-12, "Einführung der Gatling-Kanonen für die ungarische Armee."

36. See the report "Schlagfertigheit der k. ung. Landwehr," Apr. 28, 1881, KA MKSM 1881 64-4/1.

37. Kriegsgeschichtliche Abteilung des k.u.k. Kriegsarchivs, Sechzig Jahre Wehrmacht, 1848-1908 (Vienna, 1908), pp. 152-53. 
as a lever against Magyar separatism. The strongest and most populous military frontier districts, designated as regiments, existed in Croatia. ${ }^{38}$ Demilitarization of this institution had for a long time been a goal not only of the Hungarians but also of the Croatian-Slavonian civil authorities. In the wake of the Ausgleich, Andrássy was able to persuade a majority of the Croat Sabor (parliament) that it had come to terms with Hungary. Andrássy promised the Croatians a limited autonomy, including the right to have within the Honvédség special Croatian units (domobran), and also agreed that the Military Border should be joined to Croatia. ${ }^{39}$

Conclusion of this subcompromise, the Nagodba, put Andrássy in a strong position. He had always regarded the existence of the Military Borders as a potential threat to Hungary's independent status, ${ }^{40}$ and now, disregarding the promises made to Beck, he pressured Emperor Francis Joseph to agree to the disbandment of this special institution. Despite the objections from the military, Francis Joseph conceded the point that both the introduction of general conscription and the new status of Hungary had made the Borders obsolete, and demilitarization was begun in June 1871.41

The substantial gains made, however, only served to increase Hungarian aspirations. The ruling Liberal Party, devoted to the principles of the Compromise, found itself under constant pressure from the nationalist Independents. The military issue provided a popular base for attacks on the government both in and outside of parliament. To be sure, much of the agitation centered on minor matters such as insignia, standards, and nomenclature, but they served to keep resentments alive on all sides. Hungarian radical nationalists regarded the presence of the joint army in the kingdom as a provocation and a reminder of Austrian hegemony; they considered the Honvédség a mere sop to the national ego, and continued their efforts to achieve the Hungarian language of command and the wearing of national insignia in all units recruited in Hungary, including those of the joint army, and ultimately the amalgamation of all forces into one national army. This agitation, together with commemorations of the War of Independence and its martyrs, greatly angered loyalist imperial officers.

38. Gunther E. Rothenberg, The Military Border in Croatia, 1740-1881 (Chicago, 1966), and The Austrian Military Border in Croatia, 1522-1747 (Urbana, 1960).

39. Robert W. Seton-Watson, The Southern Slav Question and the Habsburg Monarchy (London, 1911), p. 372.

40. Wertheimer, Graf Julius Andrássy, and Andrássy's statements in the Ministerrat für gemeinsame Angelegenheiten, May 26, 1869, cited in Rothenberg, Military Border, p. 170 .

41. For a detailed discussion see Rothenberg, "The Struggle Over the Dissolution of the Croatian Military Border," Slavic Review, 23 (1964): 63-78. For the dissolution of the remaining border districts see the memoirs of Anton Freiherr V. Mollinary, Sechsundvierzig Jahre im österreichisch-ungarischen Heere, 1833-1879; 2 vols. (Zurich, 1905), 2:203-12, 215-21, 272-78. 
Military celebrations honoring Windischgrätz, Jelačić, and Hentzi were regarded as deliberate provocations by the Magyars. ${ }^{42}$ The military issue which Francis Joseph and Andrássy had hoped to settle for good in 1868 remained alive and was on its way to becoming "the greatest liability of the Compromise," and the "Achilles' heel of the dualistic system."43

Just how damaging this issue could become was made apparent when the Hungarian opposition was able to use obstructionist tactics in parliament to hinder the passage of army bills. Under the provisions of the Ausgleich the army structure and its finances were up for review every ten years. Beginning in 1888 the national opposition began to demand ever wider concessions, especially the formation of a purely national army. Agitation became so violent that the veteran Andrássy changed his approach and in a widely circulated speech warned against the dangers inherent in such a development. "Had we believed," he declared, "that an independent Hungarian state could not exist without an independent army ... we would not have suggested the joint defense structure." However, continued Andrássy, "because we considered the concept of an independent Hungarian army as undesirable and dangerous, not only for the monarchy but even more for Hungary, we did not even suggest this idea."44 This, of course, was not the exact truth, but with the support of the chief surviving negotiator of the Compromise, Kálmán Tisza, who by then had become prime minister and also had greatly moderated his views, was able to obtain passage of the army law. Still, passage was only achieved after Tisza had obtained additional concessions-including the change in the title of the joint army from kaiserlich-königlich to kaiserlich und königlich. ${ }^{\mathbf{4 5}}$

In 1888 the first phase in the struggle for a national Hungarian army was over, and the issue entered into a new and even more dangerous stage. Parliamentary obstruction was used again in 1898 when the common war ministry asked for a small rise in the annual recruit quota, and this time the confrontation lasted for eight years. In the end the army got its additional manpower, but too late to be of much effect in 1914, and Hungary gained artillery for the

42. Theodor v. Sosnosky, Die Politik im Habsburgerreiche, 2 vols. (Berlin, 1912), 2:167-71, and Péter Hanák, "Hungary in the Austro-Hungarian Monarchy: Preponderancy or Dependency ?" Austrian History Yearbook, 3, pt. 1 (1967): 296-97.

43. Miskolczy, Ungarn in der Habsburger Monarchie, p. 162, and Hanák, "Hungary in the Austro-Hungarian Monarchy," p. 298.

44. Die Einheit der österreichisch-ungarischen Armee: Rede des Grafen Julius Andrássy gehalten im Ausschuss des ungarischen Magnatenhauses am 5. April 1889 (Vienna, 1889), pp. 18-19.

45. William A. Jenks, Austria Under the Iron Ring, 1879-1893 (Charlottesville, 1965), pp. 245-46. On the intentions of the Magyars to use the language of command question to pave the way for a national army see the documents in Gábor G. Kemény, Iratok a nemzetiségi kérdés történeténez Magyaroszágon a dualizmus korában, 4 vols. (Budapest, 1952-66), 4:395, 301, 305-6. 
Honvédség. ${ }^{46}$ But in the meantime the conflict had brought the Dual Monarchy to the brink of civil war.

Francis Joseph had been able to impose his will on the military leaders, but developments in Hungary had caused grave apprehensions. In 1886, after some severe rioting in Buda against the joint army, Crown Prince Rudolph had expressed himself in favor of armed intervention. ${ }^{47}$ The long delay in passing necessary legislation after 1898 infuriated the military, and from 1903 on concrete plans for a full-scale military intervention in Hungary were being prepared. By April 1905 the General Staff in Vienna had worked out arrangements for Case "U."48 Loyalist units from Austria, Bohemia, and Croatia were to occupy Hungary and institute a military government. The help of the national minorities was to be sought, but no outside military help was to be invoked under any circumstances. In the end, however, though all was ready in the late summer of 1905, the emperor refused to give the order. The specter of civil war, of the revolution in Russia, and the separation of Norway and Sweden persuaded him against action. The use of minor forces coupled with further concessions resolved the crisis the following year.

The delay had greatly weakened Austria-Hungary's military posture, and she took the field in 1914 with inadequate strength and insufficient reserves. ${ }^{48}$ During the war, however, despite the dire predictions of Habsburg loyalists, Hungarian units fought with great steadfastness and loyalty, though the dream of an independent national army did not die. In fact, it remained a powerful incentive down to the very last days of the Dual Monarchy. Early in 1917 Emperor Charles finally agreed in principle to the creation of such an army, and plans to implement the undertaking as soon as the war was over were underway when the monarchy collapsed. ${ }^{50}$ When in November 1918 Hungary finally achieved her long-cherished aims-national independence and her own army-she found that this meant not only the collapse of the Dual

46. Bundesministerium f. Landesverteidigung, Osterreich-Ungarns Letster Krieg, 7 vols. (Vienna, 1930-38), 1:27-29.

47. Egon C. Conte Corti and Hans Sokol, Der alte Kaiser Franz Joseph I (Vienna, Graz, and Cologne, 1955), p. 72.

48. A detailed analysis together with pertinent documents is given by Kurt Peball and Gunther E. Rothenberg, "Der Fall ' $U$ ': Die geplante Besetzung Ungarns durch die k.u.k. Armee im Herbst 1905," Schriften des Heeresgeschichtlichen Museums in Wien, 4 (1969) : 85-126.

49. Oskar Regele, Feldmarschall Conrad: Auftrag und Erfüllung, 1906 bis 1918 (Vienna and Munich, 1956), pp. 161-64, 184.

50. Alexander Spitzmüller-Harmersbach, Der letste österreichisch-ungarische Ausgleich und der Zusammenbruch der Monarchie (Berlin, 1929), pp. 79-83. Cf. Regele, Feldmarschall Conrad, pp. 439-41. Documents include the protocol of the crown council, Dec. 4, 1917, KA MKSM 1918 38-2/1, 2, and projects for the implementation of this proposal dated as late as Sept. 12, 1918, ibid. 
Monarchy but also of the ancient Kingdom of St. Stephen, which this army had been intended to preserve.

The military compromise, though greatly modified, had managed to last for fifty years. For all their spiritual incompatibility, the joint army and the Honvédség had developed a relationship which stood the test of four and a half years of war. On the other hand, the continuing struggle for a national Hungarian army had contributed to the weakening of the internal structure of the monarchy, it had increased the tensions between the nationalities, and it had delayed expansion and reform of the joint army. ${ }^{51}$ In retrospect, perhaps, the price was rather higher than the Hungarian nationalists had envisaged.

51. See, for instance, the judgment by an English scholar: "The weakness of the Habsburg army in 1914 stemmed not from the disaffection of its soldiers but from the intransigence of politicians in Hungary." Norman Stone, "Army and Society in the Habsburg Monarchy, 1900-1914," Past and Present, no. 33 (1966): 103. 